Journal of the Scholarship of Teaching and Learning, Vol. 21, No. 4, December 2021, pp. 1-4. doi: 10.14434/josotl.v21i4.33793

\title{
Editor's Introduction: Pedagogy of the Polarized
}

\author{
Stephen E. Rahko \\ Indiana University Bloomington
}

The question of how to teach democratic citizenship has endured since the founding of the American republic and has been a central concern within the canon of pedagogical theory (Longaker, 2007). John Dewey, Paulo Freire, bell hooks, Ernest Boyer, Henry Giroux, and Martha C. Nussbaum have each made this a foundation upon which to theorize the purpose and practice of teaching (Boyer, 1990; Dewey, 1997; Freire, 2017; Giroux, 2018; hooks, 1994; Nussbaum, 2010). We are living in an era when this question has taken on greater significance, and when teachers across higher education have a more urgent responsibility to address it, than at any other period in recent American history. The significance and urgency of this pedagogical calling has only been compounded by the social, political, cultural, and technological conditions of our contemporary world that make it even more challenging to address.

When scholars, critics, and commentators describe the period of American history we are living through they use few words as frequently as they use the word "polarized." The term itself is not without controversy and its overuse in our public discourse risks making it a catch-all word to describe any form of conflict or disagreement. It is also important to stress that polarization is not always bad for democracy, for if political parties were to fail to offer points of distinction or if efforts to reduce polarization were to involve repressing certain points of view or to induce strict conformity, then democracy itself would be weakened.

Polarization, however, does threaten democracy when it becomes the basis of a social identity that encourages citizens to imagine supporters of opposing political parties, social movements, races, genders, social classes, or religious groups as enemies rather than rivals who happen to be in error. Polarization of this nature presents a crisis for democracy, particularly when a significant portion of citizens deem political violence against their enemies to be acceptable and legitimate. Recent popular work in political science, such Steven Levitsky's and Daniel Ziblatt's (2018) How Democracy's Die and Suzanne Mettler's and Robert C. Lieberman's (2020) Four Threats: The Recurring Crises of American Democracy, has documented an unsettling rise of such extreme negative and affective polarization in the United States. Polarization over issues of race, gender, class, and religion has generated an open conflict over who gets to be considered a "real" American. Yet, to this point the most consequential manifestation of the crisis of polarization in the United States undoubtedly occurred on January 6, 2021, when a violent mob stormed the U.S. Capitol as Congress was certifying the results of the 2020 presidential election.

A year has now passed since that unfortunate event, but the intensity of American polarization has not abated. Surveys published since January $6^{\text {th }}$ indicate that similar episodes of political violence in the United States are very possible in the future (Eaton, et al., 2021; Gabbatt, 2021). How are we to teach students the art of civility, dissent, ethics, judgment, as well as civic and community engagement in an era marked by such polarization along racial, class, regional, religious, gender, and sexual difference? How are we to rise to this unique historical occasion to address what conservative social scientist and democratic theorist Larry Diamond (2021) has called our "urgent imperative to repair the fabric of U.S. democracy?"

This special issue seeks to address these questions toward an interdisciplinary dialogue about how college and university faculty can respond to the challenges posed by teaching democratic citizenship in an era of social unrest, inequality, political violence, and extreme negative and affective polarization. It breaks new ground and marks the first time that any scholarship of teaching of learning 
(SoTL) or pedagogy-based peer-reviewed academic journal in the United States has addressed the question of how to teach democratic citizenship in terms of polarization.

This topic is worthy of consideration not only due to the unprecedented era we currently navigate, but also since polarization directly affects the classroom climate in which we teach. We teach in a cultural milieu marked by a fragmented and hyper-partisan media environment driven by spectacle, social media centered echo-chambers, and peer-to-peer based fake news and misinformation dissemination. Each of these developments have contributed to the spatial erosion of our public sphere by encouraging the emergence of isolated cultural silos of that could be called "self-selected safe spaces;" that is, spaces we voluntarily inhabit to surround ourselves with like-minded peers. Selfselected safe spaces can include the subdivisions and planned communities we choose to live in, as well as the religious communities and clubs we choose to belong to. Moreover, they are increasingly algorithmic and digital in nature and can include the news networks we consume and the social media networks we participate in. Polarization thrives under conditions of such social fragmentation.

While the college classroom is not immune from the poisons of polarization, it represents one of the few precious agonistic spaces we have in our culture to address the challenges of the $21^{\text {st }}$ century in thoughtful, critical, and respectful ways. Viet Thanh Nguyen (2019) argues that teachers in higher education should strive to provide a model for what a democracy should be. Henry Giroux, in his contribution to this issue, calls for a new vision of civic imagination and solidarity to renew American democracy. But what pedagogical strategies will model what democracy can be and cultivate such a new civic imagination capable of responding to the challenge polarization poses for our democracy?

The authors who have contributed to this special issue offer a compelling range of strategies for diagnosing, theorizing, and addressing the social forces and controversial topics that feed polarization. The essays reflect neither a consensus of belief nor a singular methodological approach; in fact, at times they challenge each other's assumptions and conclusions. We welcome such a rich variety of methodological and theoretical diversity in this issue, for no one method or theory will ever have a monopoly on wisdom, much less truth.

Indeed, the essays featured in this special issue are wide ranging in their scope and themes. The issue, for example, features several case studies that document institutional arrangements and oncampus diversity, equity, inclusion, and justice (DEIJ) resources for responding to the crisis of polarization. The reflective essays featured in this issue offer rich accounts of what it is means to teach in a polarized cultural space, as well as different accounts of how faculty across the academy have altered the way they teach to respond to this era. Others offer pragmatic strategies for courting our students in polarized times, be it through humor or teaching ethics, equity, and norms of professional civility.

Some essays offer critiques that map theoretical strategies for renewing and strengthening what democracy as a conceptual abstraction can and should be. The critiques featured in this special issue draw on the rich tradition of the Theoretical Humanities to offer different ways for locating polarization and the crisis of American democracy. Some, such as the essays by Kristopher Holland and Jeremy Gordon, understand the crisis of American democracy in terms of what theorists have called the "post-political" and neoliberalism. Holland and Gordon offer contrasting approaches for theorizing how the practice of education can renew democracy.

Others address the polarizing topic of race by unpacking its complexity through a diverse slate of pedagogical interventions that range from teaching racial justice and deconstructing white supremacy to fostering cosmopolitan curiosity and global citizenry through student abroad programs. Some authors offer strategies for addressing the crisis of fake news, alternative facts, and a media environment where citizens struggle to negotiate multiple "truths." Finally, many authors map strategies for renewing American democracy through enhanced civil debate and deliberation, listening, and photojournalism. Each contribution demonstrates how teaching can, in the words of Martha

Journal of the Scholarship of Teaching and Learning, Vol. 21, No. 4, December 2021. josotl.indiana.edu 
Nussbaum (2010, p. 143), "make a world that is worth living in, people who are able to see other human beings as full people, with thoughts and feelings of their own that deserve respect and empathy, and nations that are able to overcome fear and suspicion in favor of sympathetic and reasoned debate."

Finally, the editorial team at the Journal of the Scholarship of Teaching and Learning would like to dedicate this special issue to the memory of bell hooks. She taught us the existential ecstasy and joys of theoretical inquiry and teaching. I can remember the first time I encountered her timeless meditation Teaching to Transgress: Education as the Practice of Freedom during my first semester of graduate school. As I wrote this opening essay I consulted her book, and rediscovered this treasure I highlighted fifteen years ago:

I came to theory because I was hurting - the pain within me was so intense that I could not go on living. I came to theory desperate, wanting to comprehend - to grasp what was happening around and within me. Most importantly, I wanted to make the hurt go away. I saw in theory then a location for healing (hooks, 1994, p. 59).

Theory is a location for healing, and each contributing author to this special issue models an example of how theory can heal the tears and scars polarization has reaped on our democracy. Each of the manuscripts included in this volume were touched by her brilliance and penetrating insights into teaching, student learning, and cultural critique. For those of us who were fortunate enough to be inspired by her, our task now is to continue to weave the ideas she gifted us through our work so that her legacy may live on.

\section{References}

Boyer, E. L. (1990). Scholarship Reconsidered: Priorities of the Professoriate. The Carnegie Foundation for the Advancement of Teaching.

Dewey, J. (1997). Democracy and education: An introduction to the philosophy of education. Free Press.

Diamond, L. (2021, January 7). The Capitol Siege Is the Wake-up Call America Shouldn't Have Needed. Foreign Affairs. https://www.foreignaffairs.com/articles/united-states/2021-0107/capitol-siege-wake-call-america-shouldnt-have-needed

Eaton, et al. (2021, December 17). 3 retired generals: The military must prepare now for a 2021 insurrection. The Washington Post. https://www.washingtonpost.com/opinions/2021/12/17/eaton-taguba-anderson-generalsmilitary/

Freire, P. (2017). Pedagogy of the oppressed. Penguin.

Gabbatt, A. (2021, November 1). Almost one in three of Republicans say violence may be necessary to 'save' US. The Guardian. https://www.theguardian.com/usnews/2021/nov/01/republicans-violence-save-us-poll

Giroux, H. (2018). Higher Education and the Plague of Authoritarianism. symplokè. (26) 1-2. 157171.

hooks, b. (1994). Teaching to transgress: Education as the practice of freedom. Routledge.

Levitsky, S., \& Ziblatt, D. (2018). How Democracies Die. Crown.

Longaker, M. G., (2007). Rhetoric and the Republic: Politics, Civic Discourse, and Education in Early America. University of Alabama Press.

Mettler, S., \& Lieberman, R. C. (2020). Four Threats: The Recurring Crises of American Democracy. St. Martin's Press.

Journal of the Scholarship of Teaching and Learning, Vol. 21, No. 4, December 2021. josotl.indiana.edu 
Rahko

Nguyen, V. T. (2019). Why I teach. The New York Times. https://www.nytimes.com/2019/09/23/opinion/viet-thanh-nguyen-teachingdemocracy.html

Nussbaum, M. C. (2010). Not for profit: Why democracy needs the humanities. Princeton University Press.

Journal of the Scholarship of Teaching and Learning, Vol. 21, No. 4, December 2021. josotl.indiana.edu 